\title{
LA CAUSA PRO-INDÍGENA EN LA ESCUELA DE SALAMANCA DE JUAN DE PALAFOX Y MENDOZA
}

POR

\author{
A. ARístides Gámez \\ New York State University at Albany
}

Los muchos trabajos que estudian la obra del obispo Palafox realzan sus dotes religiosas y moralizadoras, pero pasan desapercibido el hecho de que Palafox es también un humanista acérrimo defensor de la causa indígena dentro de la formación de la escuela de Salamanca. La historia ha sido fiel al conservar en sus libros los hechos que inmortalizaron a Juan de Palafox y Mendoza obispo de Osma, de la Puebla de los Ángeles y virrey de México, pero las vicisitudes de los historiadores y críticos literarios han mantenido en el olvido su causa indigena.

Existe una cuasiintensa literatura relacionada con la obra política y religiosa de Palafox; ${ }^{1}$ se ha hablado de sus actos religiosos y políticos como si fueran éstos la única preocupación del obispo, ${ }^{2}$ lo cual es injusto pues basta un examen a "La naturaleza del

\footnotetext{
I Para una idea más concreta referente a la bibliografia palafoxiana véase en Sánchez-Castañer el capítulo titulado "La fama póstuma", en el cual alude a escritores que se han preocupado por rendirle homenaje al obispo por su labor religiosa. Por ejemplo, la apologética frase del Fr. Gregorio Argáiz que transcribimos: "Apagóse con su muerte una de las mejores luces que alumbraron la Iglesia; y no de las que hacen solamente sino de las que arden y lucen. Porque lucía con su letras, siendo como eran sus palabras y escritos la luz con que guiaba y enseñaba; y sus heroicas obras tan llenas de caridad y amor de Dios y del prójimo, el fuego con que ardía". Francisco Sánchez-Castañer, Don Juan de Palafox y Mendoza, Virrey de la Nueva España (Zaragoza: Editoriales del Hogar Pignatelli, 1964) $142-143$.

${ }^{2}$ Jover Zamora asevera que: "Palafox era fundamentalmente un hispanista integral que aprendió en las tierras de allende el Océano la grandeza ultraeuropea del Imperio español", José María Jover Zamora, "Sobre los conceptos de Monarquía y Nación en el pensamiento político español del XVII", Cuadernos de Historia de España de la Facultad de Filosofia y Letras (Buenos Aires: 1950) 128 y 134. Fray Domingo de Betanzos elogia las funciones desempeñadas por el Consejo de Indias que bien pudieran ser dirigidas a sus funcionarios, Palafox entre ellos, ya que él sirvió al Consejo en calidad de fiscal y consejero: "Este Consejo, - dice el padre Betanzos- en la verdad, no se había de llamar simplemente consejo, sino el más grande y soberano consejo de los consejos, en el cual todos los Consejos habían de entender, porque en él se tratan las mayores cosas del mundo, que son el acrecentamiento de muchos reinos, el de muchas gentes, el acrecentamiento de grandes rentas, la consolación de muchos tristes, la seguridad y firmeza de un nuevo mundo ..." transcrito por SánchezCastañer en su prólogo a la edición facsímil Ordenanzas Reales del Consejo de Indias, publicada por Anuario de Estudios Americanos, tirada especial del tomo XIV (Sevilla: 1957) 3. A esta cita
} 
indio" para percatarse de su labor nativista. ${ }^{3}$ Esto se explica al considerar los rasgos de la teoría política, los preceptos teológicos, incluso la retórica empleados por el obispo. ${ }^{4}$

Sobre el particular, Rojas Garcidueñas señala que: "Don Juan de Palafox fue, sin duda, mucho más político y estadista que historiador o historiógrafo". ${ }^{5}$ Apreciamos, pues,

Sánchez-Castañer añade sus propias formulaciones referentes a la preparación americana de Palafox: "No fue improvisado Palafox, para las tareas que le esperaban en Nueva España. Desde tiempo, la decisión real le había puesto en contacto con la complicada máquina del gobierno de las Indias... El 25 de octubre de 1629, fue nombrado fiscal del Consejo de Indias. Desde entonces, y hasta su nombramiento como obispo mejicano, quedó vinculado a tan alto organismo regulador de la política americanista de España". (Francisco Sánchez-Castañer, Don Juan de Palafox, virrey, 26-29). Así mismo Sánchez-Barba: "La organización de la convivencia y adecuación de la vida nacional respecto a las instituciones políticas, fueron una constante en el pensamiento de la etapa americana". José Hernández Sánchez-Barba, Historia de la literatura hispanoamericana 1492-1820 (Valencia: Editorial Castalia, 1978) 257.

${ }^{3}$ Lo verdaderamente asombroso no es la falta de materias que realcen este concepto. Enrique Gómez Haro expone: "Sería realmente, un trabajo de gran provecho para las letras españolas, la crítica elevada de las obras del V. Palafox, casi olvidadas hoy, con notoria injusticia, en el fondo de nuestras bibliotecas. Los tres libros "De la naturaleza del indio", de los cuales uno sólo ha llegado a nosotros, y que alcanzaron, por la moderación de su estilo, lo que no consiguieron las violentas declaraciones de Fr. Bartolomé de Las Casas". Enrique Gómez Haro, "El Venerable Palafox y Mendoza: Bienechor de Puebla y de los indios" (México: El Sol de Puebla, diciembre de 1959) 25.

${ }^{4}$ Vale puntualizar en este apartado que los varios críticos consultados no se percatan del nativismo de Palafox, sino que atribuyen a sus cualidades religiosas su apego a la causa pro-indígena. El mismo Sánchez-Castañer se refiere al Memorial "De las virtudes y naturaleza del indio" como un "improvisado y enjundioso alegato" escrito en defensa de los indios. Más adelante añade el crítico: "Tampoco está situado dicho Memorial en la línea de los apasionados comentarios y doctrina a favor o en contra de los indios, tan en boga durante el largo período de la presencia española en América. Quizá por todo esto (y más que nada por el olvido en que modernamente se encuentra la gran figura de Palafox) ha sido silenciado en las principales historias o monografias americanas, aunque algunas, por el enfoque de las cuestiones que tratan, lo hubieran exigido". (Francisco SánchezCastañer, Don Juan de Palafox, Virrey, 163). Sánchez-Barba alega que el "Memorial" de Palafox al rey ha sido mal interpretado por algunos críticos políticos y religiosos. Para Sánchez-Barba el Memorial es solamente un informe sobre las alabanzas que el obispo prodiga al indio: "El sentido de este tratado ha sido considerablemente desfigurado en las diversas interpretaciones que de él han sido hechas, en cuanto expresión de un excesivo sentido político o de un vinculante significado pastoral; se trata sencillamente, de una información al rey, y desde él, para la burocracia indiana, y por extensión relativa a las bases constitutivas de la realidad social ..." (Mario Hernández SánchezBarba, Historia de la literatura, 257). Greenleaf en su estudio del Tribunal de la Inquisición en la Nueva España pinta al obispo Palafox y sus actividades políticas, pero omite su labor en favor del indio: "Palafox ... As visitor General he delved into all aspects of political administration in New Spain, thereby creating deep-seeted animosities in the power structure". Richard E. Greenleaf, "The Great Visitas of the Mexican Holly Office 1645-1669". The Americas, 44/4 (April 1988), 401. Véase también el estudio de las controversias de la administración de Palafox en Jonathan I. Israel, Race, Class and Politics in Colonial Mexico 1610-1670 (London: Oxford University Press, 1975). También Charles E. Simons. "Palafox and his Critics: Reapprasing a Controversy", Hispanic American Historical Review, 46 (1966).

${ }^{5}$ En el mismo estudio Garciduefias hace un resumen de la vida política del obispo y añade: "Toda su vida, descontada la infancia, transcurrió para don Juan de Palafox y Mendoza en vínculo estrecho 
que Garcidueñas deja a un lado el resto de la obra de Palafox, especialmente "La conquista espiritual de la China" y no toma en cuenta su incansable lucha en defensa de los indios. El religioso es un humanista que cursó estudios en las universidades de Alcalá y Salamanca antes de doctorarse en Canónes en la universidad de Sigüenza. Se preparó para servir a la Corona en su capacidad de fiscal y consejero de Indias. Su nombramiento como Visitador Oficial, obispo de la Puebla de los Ángeles y más tarde virrey de México no es una coincidencia pueril.

El 25 de octubre de 1629 Palafox es nombrado fiscal de Indias; días más tarde, el 12 de noviembre, Juan de Solórzano y Pereyra publica el primer volumen de su magna obra, ${ }^{6}$ la cual trata las materias del gobierno y justicia de las Indias Occidentales. ${ }^{7}$ Hecho

con la política a través de cargos muy diversos, teniendo que velar ya por los intereses de la sociedad y la seguridad del Estado, ya con más grave peso en el apacentamiento de su grey espiritual, y mucho tiempo con responsabilidad conjunta en ambos órdenes ... todo en la insigne y santa figura de Palafox, a quien tan justamente llamó Gracián en el Discreto: "Gran espejo de prelados tan cultamente santo y erudito", cuyo amor por el pueblo mexicano lo hace tan nuestro como de España ... no dejó una Teoría del Estado o de la Política, en sentido riguroso; pero sus escritos nacidos de la experiencia constante, el amor y la buena fe, son como partes de un Ars gubernandi ... y son al mismo tiempo lazo común que en este campo asocia a Palafox con aquéllos también estadistas, predecesores unos y contemporáneos otros, ..." José Rojas Garcidueñas, Ideas Políticas de Palafox (México: Biblioteca del Estudiante, 1946) XLIV-XLVI. Otro estudioso afirma que Palafox es: "Uno de los más destacados representantes de la escuela política-moralista", Javier Malagón-Barceló, La literatura jurídica española del siglo de Oro en la Nueva España (México: 1959) 52. Así mismo la siguiente cita de Palafox transcrita por Sánchez-Castañer: "No es buen dictamen ensordecer el sentimiento en las desdichas públicas, con los públicos entretenimientos, porque se corre adelante con el engaño y con el daño; y cuanto alegra al pueblo, donde suceden los juegos y espectáculos; y trabajos; y los amigos se desaniman, y los enemigos se animan, y los neutrales se declaran ....)(Palafox, Dictámenes, volumen LXXXVII, Obras, tomo X, folio 18, 1762). El crítico concluye que el pensamiento de Palafox está dotado de realismo político y de sobrada energía: "Acostumbraba a decir la verdad la cual se sentía como puños, que no sabe como sentirían los oídos atrofiados de los gobernantes españoles a los que le tocó servir". (Francisco Sánchez-Castañer, Don Juan de Palafox y Mendoza, virrey) 26-27. Al igual la frase de Palafox que transcribe Jover Zamora revela el gran realismo político de éste: "Y hoy se halla (España) en estado que sólo Dios con su gracia y el Rey con su santo celo y valor y tan buenos ministros y vasallos como los que tiene en su servicio, pueden volverla al antiguo crédito y esplendor". (José María Jover Zamora, Sobre los conceptos, 123).

'Indiarum Lure disputatio sive de iusta Indiarum Occidentalium inquisitione, acquisitione et retentione, tribus libris comprehensa. Obra que traduce el mismo autor años después y que dio a luz bajo el título de Política Indiana.

7 Solórzano en su obra Política Indiana se opone radicalmente a las ideas del teólogo y humanista Francisco de Vitoria, asimismo se sitúa a favor de la soberanía universal del Papa. Lo cual motivó varias polémicas en la corte y en el Consejo de Indias. Otro hecho de capital significado, es el de rebatir los cargos acumulados contra España como resultados de la leyenda negra. En su estudio preliminar a Política Indiana, Miguel Angel Ochoa Brun afirma que: "Los dos primeros volúmenes del Indiarum Lure representan la primera sistematización del Derecho del Nuevo Mundo. De ahi la extraordinaria resonancia que la obra alcanzó muy pronto y las controversias que en torno a ella surgieron apenas publicada ... El primer volumen se compone de tres libros, de los que el primero lo constituye la fundamentación de la obra y los dos restantes se refieren a la justicia y necesidad de la 
significante, puesto que Solórzano era entonces el cronista oficial del reino y su libro añade combustible a la hoguera del destino del indio americano, que sin lugar a dudas causó impacto en la formación ideológica del obispo. Recordemos que las Leyes de Indias prohibían la esclavitud del indio y declaró al indio encomendado libre; uno de los capítulos de la Recopilación de las Leyes de Indias está expresamente dedicado al buen tratamiento del indio. Felipe IV en Decreto de septiembre de 1637 designó a los consejeros Solórzano, Palafox y Santalices para que adelantaran la recopilación de las Leyes de Indias. ${ }^{8}$ No es de extranar, pues, que Palafox desde su silla en el Consejo de Indias estuviese al tanto de la vida política española en las colonias de ultramar. El rey, quien sospechaba de la conducta de ciertos virreyes y otros oficiales en América, escogió de Visitador general del Reino al obispo Palafox, persona de suma confianza que sabría cumplir celosamente tan delicada misión.

En este estudio examinaremos el Memorial "La naturaleza y virtudes del indio" en el cual Juan de Palafox y Mendoza muestra una constante preocupación por el bienestar de los amerindios. ${ }^{9}$ El Memorial interesa por los datos que aporta, los cuales conducen a una serie de interrogaciones eruditas alrededor de la problemática indígena. Es interesante notar que en este memorial, el obispo hace gala no sólo de su erudición humanista, sino que muestra su valentía heroica al dirigirse al rey sin ambages, al exponerle que los indios son más virtuosos, mejores súbditos y superiores a los europeos, para lo cual pone de ejemplo las sublevaciones de Flandes (1621), Cataluña (1640) y Portugal (1640). En el Memorial se pone de relieve el apoyo a los amerindios, que incluso se manifiesta en la

conquista española de las Indias y a los títulos que legitiman la ocupación, con las discusiones que acerca de ello pueden plantearse y la refutación de las objeciones formuladas al derecho de los Reyes de España". Lo importante aquí, es realzar el contenido del segundo libro de Política Indiana, por tratar éste la problemática del indio. Ochoa Brun considera que en dicho volumen se sitúa a los indios en una posición de igualdad con los españoles: "Nuevos vasallos del Rey español, ... súbditos libres y casi equiparados a los peninsulares, salvo una cierta capitisdiminución que es más bien un privilegio y una garantía de protección". Juan de Solórzano y Pereyra, Política Indiana, Biblioteca de Autores Españoles, edición de Miguel Angel Ochoa Brun (Madrid: Atlas, 1972) XXX. Silvio Zavala también ha manifestado interés en realzar la significancia de la opinión de Solórzano: "En la Centuria siguiente a la conquista, aún repetía Solórzano Pereira que dicha tutela (del prudente sobre el bárbaro) estaba dedicada más a la comodidad del bárbaro que a la del sabio, y que la dominación de los indios de cierta cultura había de ser política, no despótica, pues eran libres por naturaleza". (Silvio Zavala, La defensa de los derechos del hombre, 43).

${ }^{8}$ Es de notar que la recopilación de las Leyes de Indias quedó suspendida con la muerte de Diego de Encina en 1582, ésta fue continuada por Diego de Zorrilla en 1603 y Rodrigo de Aguiar en 1636. Pero a pesar de la intervención de estos dos últimos, dichas Leyes no se completaron. Sobre este particular, véanse los trabajos recopiladores de Diego de Zorrilla y Rodrigo de Aguiar, en Juan Manzano, Colección de estudios Históricos, Jurídicos, Pedagógicos y Literarios (Madrid: 1936). ${ }^{9}$ En este memorial Palafox le hace ver al rey cuan fieles son los indios a la corona y con qué mérito singular la honran y sirven con obediencia y lealtad. Juan de Palafox y Mendoza, "La Naturaleza del Indio", Tratados Mejicanos II, Biblioteca de Autores Españoles, edición de Francisco SánchezCastanier (Madrid: Atlas, 1968). De ahora en adelante las citas relacionadas con este Memorial aparecen con el número de página entre paréntesis luego de cada cita. 
propensión de éstos a someterse a las reglas morales y espirituales estipuladas por la Iglesia y la Corona:

Y cuando tantas obligaciones no me pusieran en la ansia de su alivio y conservación, me ocupara todo en ella la experiencia y conocimiento práctico de las fatigas y descomodidades de estos pobres. Porque así como cada oficio de éstos no bastara a conocer las tribulaciones y penas que padecen; pero todos juntos han hecho evidencia y conclusión en mí, lo que en otros no tan experimentados puede quedar en términos de duda (91).

Como es sabido, en América las leyes se 'acataban pero no se cumplían', ${ }^{10}$ de ahí la necesidad de nuevos paladines del indio como Juan de Palafox. El incumplimiento de las leyes y la perpetuación de la desigualdad y la injusticia hacia los aborígenes americanos, obligó a Felipe IV enviar al obispo Palafox como Visitador General para que se ejecutaran sus órdenes y se supervisase a los gobernantes de la Nueva España.

Era necesario continuar en la lucha pro-indígena para lograr cambiar la injusta condición de los indios. Se ve que el empeño de los indigenistas de erradicar este mal ha sido en gran parte frustrado, como también lo fueron las prohibiciones dictadas por la Corona y las disposiciones pronunciadas por varias juntas en favor de los indígenas, como la de 1517 de los trece maestros teólogos del Convento de San Esteban en Salamanca. ${ }^{11}$

Es evidente que el cumplimiento de la misión encomendada a Palafox por el rey dependía en parte de su familiaridad con los asuntos de Indias que adquirió como miembro del correspondiente Consejo. Tuvo como modelo las polémicas provocadas por los numerosos informes allí analizados. "El Consejo de Indias - dice Román Riaza—a diario se ocupaba de los abusos que allí se denunciaban". ${ }^{12}$ Ya en tierras mexicanas cristalizó sus conocimientos con la experiencia directa y procedió a ejecutar la diversidad de las comisiones encomendadas, entre ellas, la defensa de la causa indígena.

El oficio principal de fiscal de Indias, implicaba ser protector de los indios, a quienes, a su vez, juraba favorecer (91). ${ }^{13}$ En el nuevo cargo de visitador general, sus primeras

\footnotetext{
${ }^{10}$ A este respecto Alfonso García Gallo afirma en "La ciencia jurídica en la formación del derecho hispanoamericano en los siglos XVI al XVIII", Anuario de Historia del Derecho Español 44 (Madrid, 1974) 160, que: "En una época de régimen político absoluto, en la que el rey se considera único creador de Derecho y la ley su instrumento, los reyes españoles comprometidos firmemente en la conversión de los indios ... legislan copiosamente para el Nuevo Mundo. Cualquiera que sea la vigencia efectiva de la costumbre, nunca llega a desvirtuar el régimen establecido por la ley. El supuesto desprecio de ésta por la sociedad que se considera plasma en la expresión "la ley se obedece pero no se cumple"'.

${ }^{11}$ Para estas juntas de teólogos, véase Bartolomé de Las Casas. Historia de las Indias, Biblioteca de Autores Españoles II, edición de Juan Pérez de Tudela Bueso y Emilio López Oto (Madrid: Atlas, 1957).

${ }^{12}$ Román Riaza, "Conferencias pronunciadas en la Cátedra Francisco de Vitoria, de la Universidad de Salamanca, los días 27 y 28 de enero de 1932", Anuario de la Asociación Francisco de Vitoria III (Madrid, 1930-1931) 115.

${ }^{13}$ El 14 de julio de 1633 Palafox fue promovido dentro del mismo Consejo de Indias, a Consejero, con respecto a ello Sánchez-Castaner recomienda ver la fuente harto valiosa de la historia de la
} 
instrucciones se dirigieron al alivio y consuelo de "aquellos desamparados y fidelísimos vasallos" (91) ${ }^{14}$ Es muy de notar que como virrey, sus principales instrucciones se atienen a legislar en defensa y conservación de los nativos "y con el virrey gobernador, que en sus principales instrucciones se le pone ley precisa en su defensa y conservación" (91).15

Según Palafox, los virreyes que le precedieron desatendieron su seguridad y mostraron insensibilidad ante el maltrato que les administraban los dueños de las encomiendas:

Porque los virreyes, por más despiertos que sean en el cuidado de su ocupación, no pueden llegar a comprender lo que padecen los indios; pues en la superioridad de su puesto, llenos de felicidad, sin poderse acercar a los heridos y afligidos que pena, derramados y acosados por todas aquellas provincias, tarde y muy templadas llegan a sus

\begin{abstract}
Abadía de San Salvador de Oña escrita por Fr. Gregorio de Argáiz, monje de S. Benito, profeso delreal Convento de S. Salvador de Oña. Dedicadas a los RR.os. Señores Prior y Cabildo de la Sta. y Appca. Igla. de Osma, 1660. Manuscrito en folio. Archivo de la Catedral de Burgo de Osma. (La Vida de Palafox, en los folios 424-481): "En nuestra ocupación no sólo sirvió concurriendo con los demás ministros a aquel consejo y en diversas juntas, así ordinarias, como particulares, sino en otras que su Majestad fue servido de someter sólo a su cuidado. Encargándole muchas y diversa materias y comisiones, en que dio cuenta como siempre de su cuidado" Fr. Gregorio de Argáiz, Memorias ilustres de la santa Iglesia, y Obispado de Osma. Catálogo de los Prelados que la han regido. Noticias de los claros varones que han florecido en ella y su diócesis, en santidad y en letras. Mártires y Confesores y Vírgenes. Con la vida del exemplarisimo Prelado don Juan de Palafox y Mendoza, Obispo de la Puebla de los Angeles y de Osma.

Sánchez-Castañer cita en varias ocasiones al padre Argáiz debido a que éste mantuvo una sólida reputación como historiador: "La personalidad histórica del benedictino de la Abadía de San Salvador de Oña, fray Gregorio de Argáiz, es de gran calidad. Baste con indicar que fue el continuador de las Crónicas de la Orden —-como historiador general de la misma-, iniciadas por el célebre fray Antonio de Yepes. El tono de su biografia sobre Palafox es de mucha seriedad e imparcial exposición ... Las razones o motivos de ir el P. Argáiz a Osma al lado de su Obispo, y de escribir la historia de su Iglesia y Prelados, la señala, expresamente, el propio benedictino". (Véase: Ms. cit. Sum. 8., 13 ), (Francisco Sánchez-Castañer, Don Juan de Palafox, virrey, 33).

${ }^{14}$ Hay que tener presente que Palafox fue el juez de residencia de tres virreyes de la Nueva España, en intento del rey de poner freno a los abusos contra sus vasallos. Genaro García dice a este respecto: "La Residencia de los virreyes tenía por objeto, principalmente indagar si habían ejercido su cargo con su sujeción a las facultades e instrucciones que les había dado su Majestad; si habían excedido en algo o habían agraviado a algunas personas; cómo habían manejado la hacienda real y, en términos generales, de qué manera habían servido a Dios y al Rey. Los residenciados debían de comparecer personalmente o por procurador y declarar sobre lo que se les preguntase en los plazos y bajo las penas que los jueces fijaran ..." Genaro García, Don Juan de Palafox y Mendoza, Obispo de Puebla y Osma, Visitador y Virrey de la Nueva España (México, 1918) 114-115.

${ }^{15}$ Para apoyar el tema referido nos valemos de una de las actividades de Palafox como virrey que citamos de su "Memorial al Rey", (folio 2 vuelto) transcrita por Sánchez-Castañer: "Moderó de tal manera los tratos y granjerías de los alcaldes mayores ... bajaron más de la mitad los precios excesivos de los géneros y mercaderías que vendían ... los alcaldes mayores a los pobres españoles e indios, ... no había de consentir que el Alcalde mayor, ni el Doctrinero, oprimiesen al indio, ni al español, ... ni se enriqueciesen con sangre y sudor" (Francisco Sánchez-Castañer, Don Juan de Palafox, Virrey, 46).
\end{abstract}


oídos las quejas. Y como se halla acompañada aquella gran dignidad frecuentemente de los instrumentos y sujetos que se las causa, y de los que disfrutan sus utilidades a los indios, no sólo impiden el oír los gemidos y ver las lágrimas de los oprimidos y miserables, sino que los ponen en concepto de culpados, siendo verdaderamente inocentes y sobre consumirlos con penas, se hallan también mal acreditados de culpas (91).

En su papel de visitador general, Palafox presenció la falta de cooperación de los alcaldes y doctrinarios, los que además de amenazar a los testigos, así mismo procuraban que al visitador le faltaran medios para el desempeño de su oficio. ${ }^{16}$

Palafox sirvió a Dios y al rey por los años en que la colonia ya estaba establecida, donde continuaba la tendencia de desobedecer las leyes, dado los diferentes compromisos que surgían a causa del status de los criollos y herederos de las encomiendas de los primeros conquistadores y pobladores de la Nueva España. Tal vez la fe que nutre al obispo sea ingenua, pero es claro que está persuadido de que las leyes tienen que obedecerse y por lo tanto respetarse las facultades de los indios. Sin embargo, numerosos hechos de violación de los derechos de los indígenas establecidos en la legislación confirman los abusos y el desacato a las leyes dictadas por la Corona.

En España la política indiana seguía debatiéndose bajo el plantamiento aristotélico de la teoría de la servidumbre natural. A pesar de las ideas renacentistas, las cuales sostenían que la igualdad y libertad eran indestructibles e inalienables en el hombre, algunos teólogos, juristas y oficiales se mantuvieron renuentes en su ideología de opresión. Recuérdese que la política del Siglo XVII continúa influída también por éstos y esta postura necesariamente obliga al obispo-virrey a reformar la constitución de la Nueva España.

Aunque las reformas introducidas por el obispo fueron innumerables, citamos solamente aquéllas que atañen al mejoramiento de la condición social de los indios, como su preocupación por la educación de los mismos, empresa que indudablemente agiganta su figura perspicaz. Enrique Gómez Haro en su interesante estudio afirma lo siguiente: "Pero su misión era, sobre todo, una misión reformadora, y en este terreno hay que buscarlo y estudiarlo, con preferencia, para apreciar en su justo valor la grandeza inestimable de sus trabajos" (19). ${ }^{17}$

${ }^{16}$ Este tipo de perjuicios son plasmados por los oficiales y autoridades para proteger sus intereses, como en el caso de los inquisidores señalados por Greenleaf en su estudio: "Several Inquisitors joined the Audiencia in obstructing Palafox's Visita. A November 1646 gossipy and self-serving letter to the King written by Inquisitor Juan Saenz de Manozca relates these matters ..." (Richard E. Greenleaf, The Great Visitas, 403).

${ }^{17}$ Además de su lucha por el mejoramiento de los indios, Palafox también se distinguió por haberle dado constituciones propias a la Universidad de México, hecho que permitió la diversificación de estudios y la apertura de sus puertas a gente de clases menos selectas. Al mismo tiempo fundó varios colegios para la ensenanza de lenguas y educación de los indígenas, en el mismo artículo $\mathrm{G}$. Haro expone algunas de esas obras; oigámosle: "El gran obispo fundó y dotó con 13,000 duros de renta el Colegio San Pedro ... erigió 9 cátedras de diversas facultades ... estableció un Colegio de Vírgenes para doncellas ...". (Enrique Gómez Haro, El Venerable Palafox y Mendoza, 18). Para las constituciones de la universidad, véase Genaro García, Biografia Palfoxiana (México, 19..?). También Alberto María Carreño, Efemérides de la Real y Pontificia Universidad de México, (México, 1963). 
Al igual que las Casas, considera a los indios píos e inocentes:

Y suponiendo que los indios son hombres y sujetos a las comunes miserias y pasiones de los hombres, es certísimo que respecto de otros naturales y costumbres, se pueden llamar inocentísimos: porque ninguno los habrá tratado con atención y mirado con afecto pío y cristiano, que no reconozca con evidencia moral, que están libres, en cuanto cabe en la humana fragilidad, de cuatro vicios muy capitales y otros que en el mundo suelen ser vehementísimos y los que más guerras y divisiones y discordias y pecados han causado. El primero es codicia, que no conocen los indios, ... Lo segundo, están libres de ambición que es natural en los hombres, ... Lo tercero, no conocen soberbia, sino que la misma humildad, ... Lo cuarto, apenas conocen la ira, porque son templadísimos en los disgustos, ... (101).

El obispo Palafox ha tenido la oportunidad de ver al indio ultrajado y desposeído de sus tierras y sabe además cuanto de tragedia se encierra en el alma de aquellas gentes. En su Memorial revela todo ese conocimiento y la sensibilidad que calaba en su espíritu. Solicita la intervención del rey, rematando con un argumento que encierra toda una realidad y un principio de justicia.

Y cuanto a lo secular, su trabajo (el de los indios) fecunda y hace útiles las minas, cultiva los campos, ejercitan los oficios y artes de la república, hace poderosos los de justicia, paga los tributos, causa las alcabalas, descansa y alivia los magistrados públicos, sirve a los superiores, ayuda a los inferiores, sin que haya cosa alguna desde lo alto hasta lo bajo, en que no sean los indios las manos y los pies de aquellas dilatadas provincias (105).

El obispo nos advierte que los indios por ser criaturas inocentes, son las más propensas a recibir la pureza de la fe. Contrario a los europeos, a los indios la fe los hace humanos y superiores, porque el europeo se ha dejado llevar por las herejías, mientras que el indio se ha conservado sin mancha. Su convencimiento no es superstición, ve en los amerindios una especial disposición de Dios:

Pues vemos que en tiempo del mismo Constantino Magno, padre y amparo de la católica religión, ya Arrio, y poco después Eutiques y Macedonio y otros, envenenaron las puras aguas de la cristiana y verdadera doctrina, y llevaron con perniciosos errores innumerables almas tras si; y hasta el día de hoy, poseen sus discípulos y beben y viven sus nefandísimos hijos y sucesores de aquella abominable enseñanza, y poseen con ella infamada muy gran parte de Europa [...] No así en esta cuarta parte y la mayor del mundo, la América, la cual, virgen fecundísima y constantísima, no solamente recibió la fe cristiana con docilidad y la romana religión con pureza, sino que hoy la conserva sin mancha de errores o herejías (93).

Desde tales supuestos, se infiere que el concepto aristotélico-tomista empleado por Palafox, puntualiza el significado de las virtudes del indio vistas desde una perspectiva cristiana, coincidente con la sensibilidad personal del obispo: 
Los indios ejercitan la pobreza, obediencia y paciencia, ... Y lo que es mas admirable en mi sentimiento, Señor, es que siendo tan pobres en su uso y afecto, estos naturales indios y tan desnudos, son los que visten y enriquecen el mundo, y en las Indias, todo lo eclesiástico y secular. Porque su desnudez y pobreza y trabajo, sustenta y edifica las iglesias, hace mayores sus rentas, socorren y enriquecen las religiones y a ellos se les debe gran parte de la conservación de los eclesiásticos (105).

Con respecto a las ofrendas a la iglesia los indios no se negaban a trabajar y sembrar para su parroquia al mismo tiempo que ayudaban al sustento de los sacerdotes. Oigamos a Palafox narrar la forma en que los naturales socorrían a los frailes y les suministraban sus viandas:

Y en el sustento de los ministros de la Iglesia, religiones y sus ofrendas, son así mismo muy liberales, porque ellos son, Sefior, fuera de lo que Vuestra majestad da de sus cajas, los que en toda la Nueva España sustentan los sacerdotes y religiones; ellos dan ración a los maestros de la fe, que de entrambas profesiones los doctrinan ... ellos son los que fabrican las iglesias, y esto lo hacen en cuanto ellos alcanzan y pueden, con mucha alegría, suavidad y liberalidad. Y digo en cuanto ellos alcanzan porque tal vez se les pide lo que no pueden, y entonces no hay que admirar que por que no pueden, no quieran, o lo hagan con disgusto y pesadumbre (95).

Palafox alude a los anales eclesiásticos y a los martirologios de la iglesia para dar cuenta de la sangre derramada de santos y apóstoles en su afán de esparcir la fe católica. Hace notar, sin embargo, que ese tipo de derramamientos de sangre no se sufrió en América, puesto que los indios se han sometido a la fe cristiana sin necesidad de que haya sacrificios de mártires. Por ello Palafox insiste en que el rey pondere la actitud positiva de los indios, para que los naturales encuentren un estímulo a su sumisa entrega al cristianismo, "por tan grande suavidad, docilidad y sencillez con que recibieron nuestra santa fe" (93). Así mismo advierte el proceder de los indígenas en cuanto al fervor con que demuestran su catolicismo:

En las procesiones públicas son penitentísimos y castigan sus culpas con increible fervor y esto con una sencillez tan sin vanidad, que sobre no llevar cosa sobre si que cause ostentación o estimación, van vestidos, disciplinándose duramente con incomportables cilicios todo el cuerpo, y el rostro, y descalzos mirando una imagen del Cristo señor Nuestro crucificado en las manos; y tal vez para mayor confusión llevan descubierta la cara, y esto con una natural sencillez y verdad, que a quien lo viere y ponderare, causa grandísima devoción y aun confusión (94).

Sin lugar a dudas, el encuentro del Continente Americano, "ha sido el acontecimiento más grande de la historia, después del advenimiento de Jesucristo". ${ }^{18}$ Esta opinión de

\footnotetext{
${ }^{18}$ Francisco de Gómara, Historia de las Indias (Barcelona: Editorial Librería S. A., 1854) 5. Es de notar que ésta no es una idea original de Gómara. Cristóbal Colón la incluye en su Diario de Navegación. Véanse las observaciones de Walter Mignolo al estudiar la obra de Gómara: "En la dedicatoria - afirma el crítico-, Gómara repite en sus palabras lo que había señalado C. Colón en
} 
Gómara se justifica al analizar las palabras de Jesucristo a sus discípulos "Id y envagelizad a todos", mandamiento que se cristaliza a través de la conquista espiritual del Nuevo Mundo, y con el descubrimiento de nuevas rutas marítimas hacia los otros continentes. Son, pues, los misioneros religiosos españoles, los encargados de realizar esa misión, cumplida muchas veces a través del bautismo de las masas. ${ }^{19}$ Palafox argumenta es su 'Memorial' que en las Indias se hace posible diseminar "la fe y el más glorioso triunfo de la Iglesia Católica" sobre las herejías:

Todas las naciones de Asia, Europa y Africa han recibido, Señor, la fe católica; no hay duda, porque hasta los últimos términos del orbe se oyó la voz evangélica por los apóstoles santos, [...] en la América, en donde como unas ovejas mansísimas a pocos años, y aun meses, como entró en ella la fe, se fueron todos sus naturales reduciendo a ella (93).

Añádase también, que en las Indias se reactiva la campaña de la salvación del alma del género humano, tema de mucha envergadura, dado que existían principios filosóficos que llegaron a comparar a ciertas gentes con bestias, tópico que preocupó a los teólogos que intervinieron en el concilio de Trento. ${ }^{20}$ Según la teología cristiana, el hombre no

la introducción del "Diario de Navegación": "La mayor cosa después de la creación del mundo dice Gómara- ...", "Cartas, crónicas y relaciones del descubrimiento de y la conquista", Historia de la Literatura Hispanoamericana, Tomo I, edición de Luis Iñigo-Madrigal (Madrid: Cátedra, S.A., 1982) 81.

${ }^{19} \mathrm{~L}$. Hanke al ocuparse de este tema dice: "Los frailes que sobrellevaron los más duros embates de las campañas misioneras emprendieron sus actividades con ánimo esforzado y la firme convicción de que las almas de los indios constituían la verdadera plata que debía ser extraída en América. En verdad, la conquista los obsequió con una magnífica oportunidad; puesto que la Iglesia había sido desafiada por Lutero en Europa, los frailes habían decidido que una nueva y más poderosa Iglesia debía ser levantada en el Nuevo Mundo. Se registraron estadísticas bautismales; ... creían en el bautismo en masa y asperjaban agua bendita sobre las cabezas de los indios hasta que sus manos no podían sostener ya el hisopo. Calculaban que, sólo en México, habían salvado cerca de cuatro millones de almas ...". Lewis Hanke, "Aristóteles y los indios americanos",traducción de Juan Carlos Pellegrini, Revista de la Universidad de Buenos Aires 5/3 (Buenos Aires, año 1958) 173.

${ }^{20}$ Puesto que nuestro estudio alude al tema de la salvación del alma, creemos necesario señalar que algunos europeos negaban que los indios fueran humanos y que no tenían alma; más bien éstos eran esclavos por naturaleza. En su estudio "Servidumbre natural" Silvio Zavala trata el tema del avance cristiano frente a los gentiles: "Nos referimos al planeamiento de la conquista como una dominación de hombres prudentes sobre hombres bárbaros: es decir, a una consideración del problema desde el punto de vista de la razón ..." Silvio Zavala, La defensa de los derechos del hombre en América Latina (México: Universidad Nacional Autónoma de México, UNESCO, 1982) 25. La actitud con que los religiosos enfrentan el problema del alma los induce a preguntarles a los españoles: “ ¿Éstos no son hombres? ¿Con éstos no se deben guardar y cumplir los preceptos de caridad y de la justicia? ... ¿La ley de Cristo, no somos obligados a predicársela y trabajar con toda diligencia de convertillos? ..." Citado por (Las Casas, Historia, Lib. III, cap. XCIX). El asunto de la salvación de almas era tema de fuertes disputas entre religiosos y obispos. En el año 1537, los obispos Juan de Zumárraga de México, Juan López de Zárate de Antequera y Francisco Marroquín de Guatemala respectivamente, celebraron la famosa "Junta Apostólica" para agradecer al emperador el favor de permitir a los obispos el bautismo de los naturales: “... que los curas sean puestos por el Prelado ... 
puede ser esclavo natural, especialmente si ha aceptado la fe cristiana, ya que a través del bautismo se vuelve miembro del cuerpo de Cristo y vive una vida común en Dios. ${ }^{21}$

Sabido es que desde los comienzos de la conquista y colonización de las Indias Occidentales se violaban las leyes que deberían supuestamente regir la conquista, ${ }^{22}$ inclusive llegaron a ignorarse los estatutos dictados por Isabel la Católica, que garantizaban la evangelización pacífica de los aborígenes de las tierras por descubrir y conquistar, como se ignoró también la bula Sublimis Deus promulgada por el Papa Pablo III. ${ }^{23}$ Bartolomé de Las Casas describe en su Historia de las Indias la tensión que produce la intervención humanitaria de los primeros misioneros a su llegada a las Américas, al situarse del lado de los indios al ver las calamidades que sufren los indígenas en manos de los conquistadores y encomenderos. Éstos para mejor abusar de los indios los infamaban y los declaraban inhumanos, en palabras del padre Las Casas, "los apocaron hasta decir que no eran capaces

porque somos ciertos o tenemos experiencia fue cosa muy acertada mandarlo así; porque vemos quiénes son buenos clérigos, hábiles y suficientes para tal oficio, que es lo que más es menester". Citado por (Francisco Sánchez-Castañer, Don Juan de Palafox y Mendoza, Virrey, 68). Ya en nuestros tiempos al hablar del humanitarismo español, R. M. Pidal manifiesta que el alma iguala al siervo y al amo. "La sobriedad es altamente igualitaria. La sobriedad material es la inestimable riqueza que poseen por igual tanto el pudiente como el desvalido ... El alma es el único valor del hombre, y ella hace iguales al siervo y al señor". Ramón Meléndez Pidal, Los españoles en la historia (Madrid: Espasa-Calpe, S.A., 1971) 33.

${ }^{21}$ Con respecto a la cuestión de la servidumbre natural, véase Celestino del Arenal, "La teoría de la servidumbre natural en el pensamiento español de los siglos XVI y XVII", Revista de Historiografia y Bibliografia Americanista 19-20 (Sevilla, 1975-1976). Entre otros artículos dedicados a este tema, véase Silvio Zavala, "Las Casas ante la doctrina de la servidumbre natural", Revista de la Universidad de Buenos Aires 1 (Buenos Aires, 1944). Lino Gómez Canedo, “ ¿Hombres o bestias? (Nuevo examen crítico de un viejo tópico", Estudios de Historia Novohispana 1/1 (México, 1966). Edmundo O'Gorman al estudiar el pensamiento del hombre del siglo XVI se plantea el cuestionamiento, ¿cuál era el concepto que se tenía del hombre americano?: "La polémica acerca de la verdadera naturaleza de los indios americanos ... se encuentra tejida de cuestiones religiosas, políticas y económicas. En efecto del concepto que se tuviera del indio dependía todo el programa misionero de evangelización americana y ... la cuestión de la capacidad o incapacidad de los naturales para recibir los sacramentos de la Iglesia". "Sobre la Naturaleza Bestial del Indio Americano" Revista de la Facultad de filosofia y Letras 2 (México: Imprenta Universitaria, 1941) 144.

${ }^{22}$ Sobre el interesante tema de la justicia de la guerra, véase Alfonso García Gallo, "La aplicación de la doctrina española de la guerra, (Datos para su estudio)", Anuario de Historia del Derecho Español 11 (Madrid, 1934). Es preciso citar también el estudio detallado de William Mejías López, "Las guerras en Chile y la despoblación araucana. Reacción de Ercilla y otros cronistas", Cuadernos Americanos 2 (México, marzo/abril, 1990).

${ }^{23}$ Los argumentos sobre la naturaleza de los indios no cesaron después de la reforma de las Leyes de Indias. Como prueba a la desobediencia de algunos españoles con respecto al trato que deberían de darle a los indios surge la bula Sublimis Deus, que el Papa Pablo III consideró necesario dar en 1537. El Papa dejaba establecido que los indios no eran animales al servicio de los españoles, sino hombres capaces de recibir la fe cristiana: “... Tales indios y todos los que más tarde se descubran por los cristianos, no pueden ser privados de su libertad por medio alguno, ni de sus propiedades, aunque no estén en la fe de Jesucristo ... y no serán esclavos". Citado por (Lewis Hanke, Aristóteles y los indios, 173). 
de la fe, que no es chica herejía, y hacellos iguales de bestias". ${ }^{24}$ La curia de la Española asignó a Fr. Antonio de Montesinos leer el primer mensaje de desaprobación de la obra colonizadora Ego vox clamantis in deserto. ${ }^{25}$ El sermón del dominico censuraba drásticamente los ultrajes y abusos de los españoles contra los indios y señalaba el pecado de desobediencia de los colonizadores: Su voz hizo temblar al púlpito y se dejó oír en toda la isla. Años más tarde se llevó a cabo la polémica que teóricamente discutiría la verdadera naturaleza de los indios, su condición de esclavo y/o de hombre libre. ${ }^{26}$

La labor humanitaria iniciada por los dominicos en la Española, provocó acaloradas controversias tanto en la isla como allende el mar Océano. El catedrático de Salamanca Francisco de Vitoria, aprovechó y entretejió con el pensamiento aristotélico- tomista, las noticias que llegan desde las Indias, para así refutar las ideas, no menos aristotélicas de la guerra justa y la esclavitud natural del indio. ${ }^{27}$ La voz de Montesinos y las formulaciones de la escuela de Salamanca resuenan en el Padre Las Casas como en Juan de Palafox, cuyos conceptos son los puros principios cristianos proclamados por Francisco de Vitoria en 1539.

Ya desde el hallazgo del Nuevo Mundo, los religiosos trataron en repetidas ocasiones de establecer que los indios no deberían de ser considerados infieles, ni mucho menos animales. Palafox reitera que América representa el patrimonio que producía ingresos a la Corona:

Y si las Indias, sus provincias y reinos, sobre merecer la merced que Vuestra Majestad les hace por no haber costado mucho a la Corona, la merecen por haberla enriquecido con tan copiosos tesoros, cuales nunca se vieron en el mundo, siendo suyo sólo el darlos y de los ministros lograrlos. Y es, sin duda, que para las continuas guerras del seffor Emperador Carlos V y serenísimos Felipe II y III, su hijo y nieto, y las frecuentes y

${ }^{24}$ Bartolomé de Las Casas, Historia ..., Libro III, capítulo 8.

25 "Ego vox clamantis in deserto ... yo soy voz de Cristo en el desierto desta isla, ... Todos estáis en pecado mortal y en él vivís y morís, por la crueldad y tiranía que usáis con estas inocentes gentes. Decid, ¿con qué derecho y con qué justicia tenéis en tan cruel y horrible servidumbre aquestos indios? ... Tened por cierto, que en el estado que estáis no os podéis más salvar que los moros o turcos que carecen y no quieren la fe de Jesucristo". Citado por (Fray Bartolomé de Las Casas, Historia de las Indias, Libro III, capítlo 8). Obsérvese que en esta última frase, Montesinos nos previene que los herejes (moros y turcos) no podrán salvar su alma. Es de notarse que en los escritos lascasianos y palafoxianos se advierten intenciones similares. Ambos humanistas no encubren su propósito de afirmar que los indios no son infieles, sino vasallos del Imperio.

26 “Adviértase, pues - nos previene O'Gorman con respecto a la magnitud del dilema que suscita la dialéctica sobre el pensamiento aristotélico-, la enorme importancia que revestía el problema. Por eso, nada de sorprendente tiene que en la polémica se tercien los nombres de todos los más eminentes representantes de la intelectualidad española de la época". (Edmundo O'Gorman, Sobre la Naturaleza Bestial, 141-158).

${ }^{27}$ En palabras de García Gallo: “... Francisco de Vitoria aplica el Derecho natural en toda su totalidad, no sólo en cuanto afirma los derechos de los indios, sino también sus deberes y los derechos y deberes de los españoles. El Derecho natural se convierte en 'Derecho de gentes'. (Alfonso García Gallo, La ciencia juridica en la formación, 166). Para la ideología del derecho de gentes formulado por F. de Vitoria, véase Alfonso García Gallo, La aplicación de la doctrina, 1934. Asimismo, Francisco de Vitoria, Relaciones teológicas, edición de T. Urdanoz (Madrid: Biblioteca de Autores Cristianos, 1960). 
pesadas que Vuestra Majestad ha tenido para defender la Iglesia y la fe y su dignísima Corona y Casa, han importado tanto los socorros de las Indias, cuanto se puede fácilmente reconocer de los que han venido desde el año de 1523 hasta ahora y de los que han faltado cuando por algún accidente no han llegado, que ha causado dañosísimos efectos (110).

Palafox asevera que las riquezas sirven para mantener al gobierno activo, pero éstas también son un instrumento de "salvación y de perdición": de perdición "si las gastamos en vicios y de nuestra salvación si las damos honesto, santo y cristiano empleo" (100).

Reconózcanse, Señor, las historias y crónicas de todos los reinos y provincias de Europa, que no se hallará ninguna en la cual, por fidelísimos que sean sus moradores, no hayan padecido muchas enfermedades políticas, frecuentes a los cuerpos públicos de las naciones, despertándose y levantándose guerras con sus reyes o gobernadores; unas veces sobre privilegios, otras sobre tributos, otras sobre derechos o inteligencias de príncipes confinantes y poderosos; humores que revuelven los de los reinos, los cuales sobre la sangre que costaron a los conquistadores al conquistarlos, le hacen a la Corona derramar mucha al gobernarlos.

Y esta nobilísima parte del mundo, sobre haber costado a la Vuestra Majestad y a España poquísima sangre, respecto de su grandeza al sujetarse, no ha costado ni gastado copia considerable al conservarse y mucho más la de la Nueva España, que entre todas las de este Nuevo Mundo ha sido pacífica y leal (97).

Se entiende, entonces, que los indios siempre fueran considerados súbditos del reino de Castilla. Recuérdense las declaraciones de la reina Isabel al almirante Colón, cuando éste intentó granjear algunos esclavos indios en Sevilla; la reina se refirió a los indios como sus 'vasallos'. ${ }^{28}$ “QQué poder tiene mío Almirante para dar a nadie mis vasallos?”.

Las Casas insiste en la importación del oro extraído de las Américas, éste sirve para hacer guerra a los infieles y los que amenazan el Imperio. Pongamos énfasis en que Palafox no es parco en revivir el tema y reincide en que los indios no le han costado vidas y dinero a la Corona, contrarrestando lo que está sucediendo en los Países Bajos:

Antes es muy loable y de gran mérito que cuando muchos reinos, como, los países Bajos y otros de esta calidad, no han tributado renta considerable a la Corona y ella les ha tributado gente, riquezas, sangre y costado tantas guerras, hayan los de las Indias, sin costarle sangre ni plata, ni oro, ofrecido cuanto la tierra ocultaba dentro de sus entrañas (100).

Observamos que de las Indias se obtiene el dinero para la defensa de la iglesia y del reino:

${ }^{28}$ El humanista Gómara en su dedicación de su obra al Rey Carlos V, se dirige a él manifestándole que los indios americanos son "súbditos del Emperador", (Francisco de Gómara, Historia de la Indias, 5). Ramón Menéndez Pidal ha hecho notar que: “... la reina siempre consideró a los indios como vasallos al igual que los castellanos”. El crítico además manifiesta que: “... el Rey Católico invoca igualdad de todas las razas como idea básica de la colonización ..." (Ramón Menéndez Pidal, Los españoles en la historia, 34). 
Así como los indios son vasallos que menos han costado a la Corona, no son los que menos la han enriquecido y aumentado. Porque no puede dudarse, que muchos de los demás reinos de Vuestra Majestad y de otras coronas que hay en el mundo, aunque se consideren juntas, no igualan ni llegan a la menor parte de los tesoros que en tan breve e tiempo ha fructificado la Nueva España en las minas del Potosí, Zacatecas, el Parral, Pachuca, Guanajuato y otras; y en los tributos, alcabalas, tercios de oficios y diversos géneros de renta, y esto sin hacer consideración de lo que mira al Perú (100).

La confraternidad humana del obispo pasa de simpatía a admiración del coraje, la destreza y la valentía con que los indios se defendieron durante la conquista, pese a la desventaja de sus armas:

Porque, sin embargo, de ser la ventaja de las armas de los nuestros tan grande, que los indios peleaban con palos y piedras, $y$ los otros con espadas y arcabuses, ... hubo un indio que habiéndole atravesado con una lanza el cuerpo fue caminando por ella misma hasta llegar al soldado que la tenía empuñada y herido, y muriendo se la quitó de las manos (98).

Esas palabras de reconocimiento que encontramos en el Memorial no están ahí por capricho o por un afán de exaltar la dignidad indígena. Por el contrario, la alabanza es necesaria si se quiere proceder con imparcialidad. De ahí que se preocupa tanto en revelar tan significantes anécdotas, para ilustrar con ejemplos su natural defensa de los indios.

Palafox estudia, expone y valora todos los aspectos de las medidas pertinentes a la política social que realiza España con los amerindios, y así mismo defiende la política de la metrópoli:29 "Los españoles, Señor, que son tan despiertos y entendidos, y nación tan belicosa y valerosa ..." (98). Palafox exculpa frecuentemente a los indios de las acusaciones en que les tildan de perezosos, herejes y otros sustantivos peyorativos: ${ }^{30}$

${ }^{29}$ El historiador Jover Zamora afirma que el pensamiento de Palafox es defensivista: "Es decir, veía en la Monarquía un cuerpo inmenso universal, que no había de pensar en incorporar a su dominio nuevas tierras, sino en impedir que los enemigos le arrebatasen plazas. Segundo: esta Europa enemiga nuestra, estaba perdida para la causa de la Religión y de las buenas normas de antaño. Palafox, es, pues, catastrofista. Y tercero: por el sentido dinámico que, en el mundo de su utopía política, debía informar a la Monarquía; por su incomprensión de la política europea; por su catastrofismo; tal vez también por su prolongada experiencia americana", (José María Jover Zamora, "Sobre los conceptos", 123).

${ }^{30}$ Lewis Hanke en su estudio de la polémica sostenida entre Juan Ginés de Sepúlveda y Bartolomé de Las Casas en 1550, alude a la intención de Sepúlveda de aplicar la doctrina aristotélica a la esclavitud de los amerindios: "Sepúlveda argumentaba que la antigua teoría que clasificaba a ciertos grupos de personas como inferiores por naturaleza, nacidos de hecho esclavos, era aplicable en grado sumo a los indios paganos y justificaba que los españoles les hicieran la guerra para forzarlos a aceptar el cristianismo". Más adelante el crítico afirma que "Éste es uno de los aspectos más esclarecedores del carácter español y de la época. Vemos aquí también el primer intento en los tiempos modernos de estigmatizar a toda una raza como innatamente inferior" (169). En el mismo estudio, Lewis Hanke hace notar la debilidad de fray Domingo de Betanzos al llamar a los indios bestias e incapaces para asimilar la doctrina cristiana: "Los frailes también seguían estando en desacuerdo sobre la naturaleza de los indios. Un dominico llamado Francisco de Betanzos tuvo una 
Y cuanto a la pereza, que es muy propia de ellos, por ser tan remiso y blando su natural, no hay que cuidar de exhortarlos a la diligencia y trabajo corporal; ... Y de aquí se deduce, Señor, una manifestación evidente de la virtud de los indios, pues de siete vicios capitales que traen al mundo perdido, se halla su natural, comúnmente hablando, muy exento y moderado, ... (103).

Proclama que su fe es justa y que siguen con devoción el dogma católico. ${ }^{31}$ Recomienda regular las horas de trabajo y su justa retribución; a su vez exige se proteja y dignifique a los nativos,

y ellos, Señor, y yo, y todos cuantos bien los queremos y solicitamos su alivio, nos contentaremos con que padezcan y trabajen y fructifiquen, como sea con un moderado y tolerable trabajo y pena. Y solo represento sus méritos y virtudes, para que Vuestra Majestad se sirva de ampararlos en el padecer intolerable (105).

Si durante su estadía en América el obispo Palafox se dedicó concienzudamente a preparar una justa defensa y a desvelar los problemas que atanían a los nativos, a su regreso a España expone esta defensa en su memorial a Felipe IV,

con que este conocimiento, y el que tengo de la piedad de Vuestra Majestad y cuán grato servicio le haremos sus ministros y prelados en darle motivos a hacer las leyes mas eficaces en su ejecución, siendo en su decisión santísimas, ... solicitando a la clemencia de Vuestra Majestad y santo celo de sus ministros a que animen estas leyes y las vivifiquen con su misma observancia ... (92).

Justifica la justicia regia por su carácter divino, al mismo tiempo recuerda a la Corte que la distancia produce que las leyes pierdan efectividad y que las células reales no se respeten:

vez la sensación de que los indios eran tan incapaces como niños y aun les aplicó el término bestias en un memorial escrito que presento al Consejo de Indias". (Lewis Hanke, Aristóteles y los indios americanos, 173). Concerniente a la conducta del sacerdote aludido el padre Padilla al tratar sobre la vida de Fray Domingo de Betanzos, dice: “... Hubo gente, y no sin letras, que puso duda en si los indios eran verdaderamente hombres, de la misma naturaleza que nosotros; y no faltó quien afirmase que no lo eran, sino incapaces de recibir los santos sacramentos de la Iglesia”. Agustín Dávila Padilla, Historia de las fundaciones y discurso de la provincia de Santiago de México de la orden de Predicadores, Libro I, capítulo 30, (México). Bajo el mismo tema del concepto aristotélico véase también la opinión que Gregorio López de Tovar sostiene acerca de los indios, este erudito los trata de "animales que hablan" y que son "siervos por natura". Citado por Las Casas, Historia ..., Libro III, capítulo XII).

${ }^{31}$ Lewis Hanke ha escrito sobre este fenómeno concerniente a las cualidades positivas del indio: "Debido a que los españoles se vieron tan perturbados por su contacto con los indios, pocas figuras significativas de la conquista dejaron de dar a luz sus opiniones sobre la naturaleza de los indios, su capacidad de trabajo y aptitud para la civilización cristiana. El Consejo de Indias instituyó prolongadas y formales indagatorias sobre la materia: entre la documentación de los archivos hispanos hay numerosas y curiosas propuestas para la protección de los indios". (Lewis Hanke, Aristóteles y los indios, 170). 
Porque las leyes sin observancia, Señor, no son mas que cuerpos, arrojados en las calles y plazas, que solo sirven de escándalo de los reinos y ciudades en que tropiezan los vasallos y ministros, con la trasgresión, cuando habían de fructificar observadas y vivas toda su conservación, alegría y tranquilidad.

Por esto me ha parecido, que era buen medio proponer a Vuestra Majestad las cualidades, virtudes y propiedades de aquellos utilísimos y fidelísimos vasallos de las Indias, y describir su condición sucintamente y referir sus méritos, porque todo esto hace en ellos mas justificada su causa y en Vuestra Majestad mas heroica y noble la razón de su amparo (92).

La fe recia del obispo le hizo presa de la persecución por parte de la Compañía de Jesús en los últimos años de su obispado en Puebla. ${ }^{32}$ Aparte de lo que pueda decirse sobre la inquisición en la Nueva España en esos días, parece revelar que Juan de Palafox contaba con la antipatía de gente poderosa en México, y las mezquinas amenazas de parte del arzobispo-inquisidor llegaron a provocar una crisis en sus actividades parroquiales, obligándolo a huir de Puebla para salvar su vida.

Fue en suma Palafox un espíritu en que se aunaron a una fe cristiana ejemplar, el cultivo de las buenas letras, los anhelos de reforma y el respeto al Rey. Su Memorial "De la naturaleza y las virtudes del indio" constituye el documento que plasma su labor en favor de los indígenas de la Nueva España. Así mismo realza su fina sensibilidad, su alma de poeta, su fe y su espiritualidad de formación humanista. Juan de Palafox y Mendoza se encuentra entre aquéllos que en los siglos XVI y XVII se ocuparon de la problemática de los indios de la América española. Las Casas y Palafox coinciden al examinar la cuestión del tratamiento de los indios y la manera de llevar a la práctica las leyes revisadas en el Consejo de Indias. Asimismo, el obispo de Puebla propone no sólo el argumento de la dignidad del indígena, sino el de su superioridad. Celebremos a Las Casas, pero no olvidemos la valentía de Palafox.

\footnotetext{
${ }^{32}$ Aunque la oposición jesuítica al proceso pro beatificación de Palafox es ajena a nuestro tópico, la consideramos pertinente al presente estudio, dado que al ser llamado el obispo a España; funcionarios oficiales y miembros de la Compañía se opusieron a que a Palafox se le concediera volver a México a continuar con su ministerio y con la defensa de los indios. Es de notar que al descubrir las nulidades del gobierno de la Compañía, Palafox fue acusado por ésta de jancenista y se opuso a la canonización del obispo en el siglo XVI. Para una mejor interpretación del conflicto Palafox y la Compañía remitimos a los interesados a la lectura del manuscrito "REFLEXIONES DEL SR. DN. JOSEPH NICOLÁS AZARA, AGENTE Y PROMINISTRO DEL REY CATÓLICO EN LA CORTE DE ROMA SOBRE LA GENERAL CONGREGACIÓN QUE SE TUVO EN EL PALACIO VATICANO EN PRESENCIA DEL PAPA PIOO VI, SOBRE LAS VIRTUDES EN GRADO HEROICO DEL VENERABLE SR. DN. JUAN DE PALAFOX. DÍA 28 DE ENERO DE 1777. Documento transcrito por Francisco Sánchez Castañer en su artículo "El Embajador Azara y el proceso de beatificación del Venerable Palafox", Revista de Indias, 31/123124, (January-June, 1977). Se han demostrado otros detrimentos contra el obispo por parte de los jesuitas en el interesante artículo de Greenleaf: “The Tribunal's partisan stance in Palafox's controversy with the Jesuits erupted into the cause celebre of the seventeenth-century and no doubt the monarchy, the Council of the Indies, and the Suprema to take punitive action against the Mexican Inquisitors. Palafox's troubles really began in May 1642 when he was made Archbishop followed by his June 9, 1642, appointment as Viceroy, ... Palafox's assumption of power as Archbishop also ranked the hierarchy, and, or course, the Audiencia of Mexico had been outraged by his assumption of both political and judicial power ...". (Richard E. Greenleaf, The Great Visitas, 403-404).
} 